\title{
Exclusive breastfeeding practice and sources of support during COVID- 19 pandemic in Indonesia
}

\author{
Cahya Ayu Agustin ${ }^{1,2}$, Judhiastuty Februhartanty ${ }^{2 *}$, Saptawati Bardosono ${ }^{1}$ \\ ${ }^{1 *}$ Department of Nutrition, Faculty of Medicine, Universitas Indonesia - Dr. Cipto Mangunkusumo \\ Hospital, Jakarta, Indonesia Email: s2s3ilmugizi.fk@ui.ac.id, Phone: +62-21-31930208 \\ ${ }^{2}$ Southeast Asian Ministers of Education Organization - Regional Centre for Food and Nutrition (SEAMEO \\ RECFON)/Pusat Kajian Gizi Regional (PKGR), Universitas Indonesia, Email: information@ seameo- \\ recfon.org, Phone: +62-21 22116225 \\ *Address for correspondence : jfebruhartanty@ seameo-recfon.org
}

\begin{abstract}
In 2018, the national coverage of exclusive breastfeeding among infants aged 0-5 months in Indonesia was still low. The COVID-19 pandemic can be a challenge to increase the coverage of exclusive breastfeeding. This study investigated the association between sources of breastfeeding supports and exclusive breastfeeding practices among mothers with infants aged under 6 months during the COVID-19 pandemic in Indonesia. This study used a cross-sectional study design through an online survey from November 2, 2020, to February 8, 2021. A total of 248 subjects were obtained through convenience sampling. Data analysis was done by bivariate analysis using Chi-square or Fisher's exact test. Most of the subjects were aged 18-34 years old (90.7\%), had higher education level (86.7\%), had household income range Rp.3,000,000 - Rp.7,199,999 $(39.2 \%)$, lived in Java Island (83.1\%), had an infant aged $\leq 4$ months $(76.2 \%)$, and had a baby boy (51.2\%). The proportion of exclusive breastfeeding was $79.0 \%$. The most common sources of breastfeeding support were obtained from husband (91.1\%) and health workers (65.7\%), followed by family (62.9\%). No significant association was found among all support sources on breastfeeding with exclusive breastfeeding. However, the proportion of exclusive breastfeeding among mothers who received husband support (80.1\%) was higher than those who did not (68.2\%). The most convenient and feasible breastfeeding supports that mother could obtain during pandemics were home-based supports. Mothers, their husbands, and families should be the priority target for health professionals to provide preventive and promotive breastfeeding intervention.
\end{abstract}

Keywords: COVID-19 pandemic, exclusive breastfeeding, family support, husband support, Indonesia.

\section{ABSTRAK}

Cakupan nasional pemberian ASI eksklusif pada bayi usia 0-5 bulan di Indonesia masih rendah pada tahun 2018. Pandemi COVID-19 dapat menjadi tantangan dalam usaha peningkatan cakupan pemberian ASI eksklusif. Penelitian ini bertujuan untuk mengetahui hubungan antara sumber 
dukungan menyusui dengan praktik pemberian ASI eksklusif pada ibu dengan bayi berusia di bawah 6 bulan selama pandemi COVID-19 di Indonesia. Penelitian ini menggunakan desain studi potong lintang melalui survei daring selama 2 November 2020 - 8 Februari 2021. Sebanyak 248 subjek diperoleh secara convenience sampling. Analisis data melalui analisis bivariat menggunakan uji Chi-square atau Fisher's Exact. Sebagian besar subjek berusia 18-34 tahun (90,7\%), berpendidikan tinggi (86,7\%), memiliki pendapatan rumah tangga berkisar Rp3.000.000 Rp7.199.999 (39,2\%), berdomisili di Pulau Jawa (83,1\%), memiliki bayi usia 4 bulan $(76,2 \%)$, dan memiliki bayi laki-laki (51,2\%). Proporsi pemberian ASI eksklusif sebesar 79,0\%. Sumber dukungan menyusui terbanyak diperoleh dari suami (91,1\%) dan petugas kesehatan $(65,7 \%)$, diikuti oleh keluarga $(62,9 \%)$. Tidak ditemukan hubungan yang signifikan antara semua sumber dukungan menyusui dengan ASI eksklusif. Namun, proporsi pemberian ASI eksklusif pada ibu yang mendapat dukungan suami $(80,1 \%)$ lebih tinggi dibandingkan dengan ibu yang tidak mendapat dukungan suami $(68,2 \%)$. Dukungan menyusui yang paling mudah dan mungkin untuk diperoleh ibu selama pandemi adalah dukungan berbasis rumah. Ibu, suami, dan keluarga harus menjadi sasaran prioritas bagi tenaga kesehatan untuk memberikan intervensi pemberian ASI secara preventif dan promotif.

Kata kunci: ASI Eksklusif, dukungan keluarga, dukungan suami, Indonesia, pandemi COVID-19.

\section{INTRODUCTION}

Indonesia is facing the triple burden of child malnutrition. Data in 2018 show the prevalence of children under 5 years old with underweight, wasting, and stunting were $10.2 \%$, $17.7 \%$, and $30.8 \%$, respectively. Child obesity was $8.0 \%$, slightly decreasing from $11.9 \%$ in 2013 . Child anemia was $38.5 \%$, increased from $28.1 \%$ in 2013 [1$3]$. Furthermore, the emergence of the Coronavirus disease-19 (COVID-19) pandemic has impacted global public health, including child health and nutrition due to the disruption of the health system, socio-economic, and food system. These disruptions are potentially exacerbating the challenges of malnutrition problem among children $[4,5]$.

Infant and young child feeding, especially exclusive breastfeeding up to 6 months and breastfeeding up to 12 months, is a proven strategy to achieve optimal child growth and development $[6,7]$. Thus, breastfeeding remains to have an important role in preventing lifethreatening infections in infants and young children during the COVID-19 pandemic [8]. Unfortunately, even before the COVID-19 pandemic, the national coverage of exclusive breastfeeding among infants aged 0-5 months in Indonesia was $37.3 \%$ in 2018 [1] which is still far from both the targets of the WHO [9] and the government's mid-term plan of $50 \%$ by 2025 [10].

There are multiple determinants of exclusive breastfeeding, which range from individual setting to structural-level in normal circumstances [6,11]. However, there will be further challenges to ensure exclusive breastfeeding practices during such an infectious disease pandemic. It is plausibly due to the indirect effects of a pandemic on the associated factors of exclusive breastfeeding [12,13]. Furthermore, restriction of movement and the separation from the loved ones or other family members, lossing freedom, fears of disease, and changes in income and job, can lead to negative psychological effects, especially for vulnerable groups such as pregnant mothers and new mothers $[14,15]$.

To date, several studies have already observed the impacts of the COVID-19 pandemic among breastfeeding mothers, but there are still limited studies that investigate the association between sources of 
breastfeeding supports with exclusive breastfeeding practices during pthe andemics. It is important to investigate this association to provide a greater understanding of the pandemic impacts to find the effective strategies to improve exclusive breastfeeding practices. Therefore, this study aims to investigate the association between sources of breastfeeding supports with exclusive breastfeeding practices among mothers with infants aged under 6 months during COVID-19 pandemic in Indonesia.

\section{METHODS \\ Study design, sample, and sampling procedure}

This study was conducted as a quantitative study using a cross-sectional study design. It is part of the COVID-19 Mom-Baby Study conducted in the UK and Malaysia. Data collection was carried out online from $2^{\text {nd }}$ December 2020 to $8^{\text {th }}$ February 2021. The study population was mothers above the age of 18 years old, who were currently living in all regions of Indonesia and have an infant aged under 6 months ( $<183$ days). All mothers with a different type of infant (e.g. twin, premature, low-birth weight, or any type of medical conditions) and a different type of infant feeding practices (breastfeed, formula-fed or mixed-fed) were eligible to participate in this study. Subjects who were eligible and gave online consent became the study participants, except those who were pregnant.

The sample size was calculated based on the multivariate analysis used in the COVID-19 Mom-Baby Study. This calculation involved a rule of event per variable (EPV) requiring a minimum sample size needed of 10 cases per independent variable [16]. With 21 variables consisting of maternal, infant, and household characteristics, the maternal risk for COVID-19 and mood, as well as sources of breastfeeding support used in the project, added with $10 \%$ for incomplete cases, the total samples required was 231 subjects. However, the present study focuses only on maternal-infant characteristics and breastfeeding support.

The subjects were taken using non-probability sampling with convenience sampling techniques. The survey invitation with a link of the online questionnaires through the Limesurvey ${ }^{\circledR}$ platform was advertised and distributed on websites and social media pages of SEAMEO RECFON and Department of Nutrition, Faculty of Medicine, Universitas Indonesia, as well as the research team's contact through social media and messenger services. The research team also collaborated with relevant organizations working in the maternal and child health to disseminate the survey invitation through their networks and/or social media accounts.

\section{Instrument}

The instrument used in this study was an online structured questionnaire adapted from the UK COVID-19 New Mum Study developed by University College London (UCL). The questionnaire has five parts; A) Sociodemographic characteristics of Mother and Infant (25 questions), B) Current Infant Feeding Practices (39 questions) and Household Food Security (18 questions), C) COVID-19 Pandemic and Its Impacts (21 questions), D) Infant feeding and behavior and any changes due to COVID-19 pandemic (52 questions), and E) Mother's Activities, Mood and Access to Support during COVID-19 Pandemic (34 questions). Questions related to current infant feeding practices or breastfeeding practices were based on Indonesia Basic Health Research 2018 and Indonesia Demographic and Health Survey 2017 $[17,18]$. Some questions were adapted to 
the Indonesian situation and the final Indonesian questionnaire was pre-tested.

\section{Measures}

Mother's and infant's characteristics: $\quad$ sociodemographic characteristics of mother, including maternal age, educational level, household income level in the last 1 month, mother occupation during the pandemic, and living location. Infant profiles were asked, including date of birth, sex, birth weight, and gestational age. Sources of infant feeding support were assessed based on the mother's answer to question "Where do you get support with infant feeding from?". The breastfeeding patterns were defined according to World Health Organization (WHO) definition [19]. Exclusive breastfeeding definition was infants who were received only breast milk including milk expressed or from a wet-nurse, without any additional solid or liquid supplement including water, except oral rehydration solution (ORS), drops, or syrups (e.g. vitamin, minerals, medicines) from the previous day.

\section{Data collection procedure}

The eligible subjects who have received the survey invitation and interested to take part in this study could fill the questionnaire directly through the survey link bit.ly/mombabystudy. At the beginning of the questionnaires, a brief description of the survey, research purpose, and benefits were provided. Initial validation confirmed each eligibility criterion using screening questions. Data quality assurance measures taken included 1) providing CAPTCHA [20] 2) Name, email, phone number, and IP-address checking [21,22]

3) Time speed, attention check question, and pattern answer checking [21,23], and 4) Confirmation to the respondents through messager services or telephone if any inconsistent, missing, or implausible data were found.

\section{Statistical analysis}

Univariate analyses presented in frequency and percentage were done to provide descriptive characteristics of subjects on the exclusive breastfeeding practices and the sources of support. Bivariate analysis using Chi-square or Fisher test was performed to show the association between the exclusive breastfeeding practice and its sources of support with the significant level set at $\mathrm{p}<0.05$. All analyses were performed by using IBM SPSS Statistics 20.0.

\section{Ethics}

Ethical approval was obtained from the Ethics Committee of the Faculty of Medicine, Universitas Indonesia Dr.Cipto Mangunkusumo Hospital (KET 357/UN2.F1/ETIK/PPM.00.02/2020).

\section{RESULTS}

During data collection from 2nd December 2020 to 8th February 2021, a total of 1,214 responses were obtained. Among those responses, a total of 538 responses were excluded with following reasons: 251 responses did not fill the online survey at all, 73 responses did not pass the screening questions, 455 responses had an infant aged 6 months or above, 3 responses were from a male respondent, did not have an infant, and whose infant was not the respondent's child, 131 responses did not complete infant feeding practices section. Therefore, there were 301 responses with infants aged (under 6 months or $<183$ days). However, there were 5 duplicate responses identified from the identical name, email address, and phone number. We included those with complete responses and when both duplicate responses were completed, only the recent one was included in this study. The total responses with infants aged under 6 
months was 296 with 48 excluded responses due to incomplete data. Therefore, the total responses included as subjects in this study were 248 subjects (Figure1).

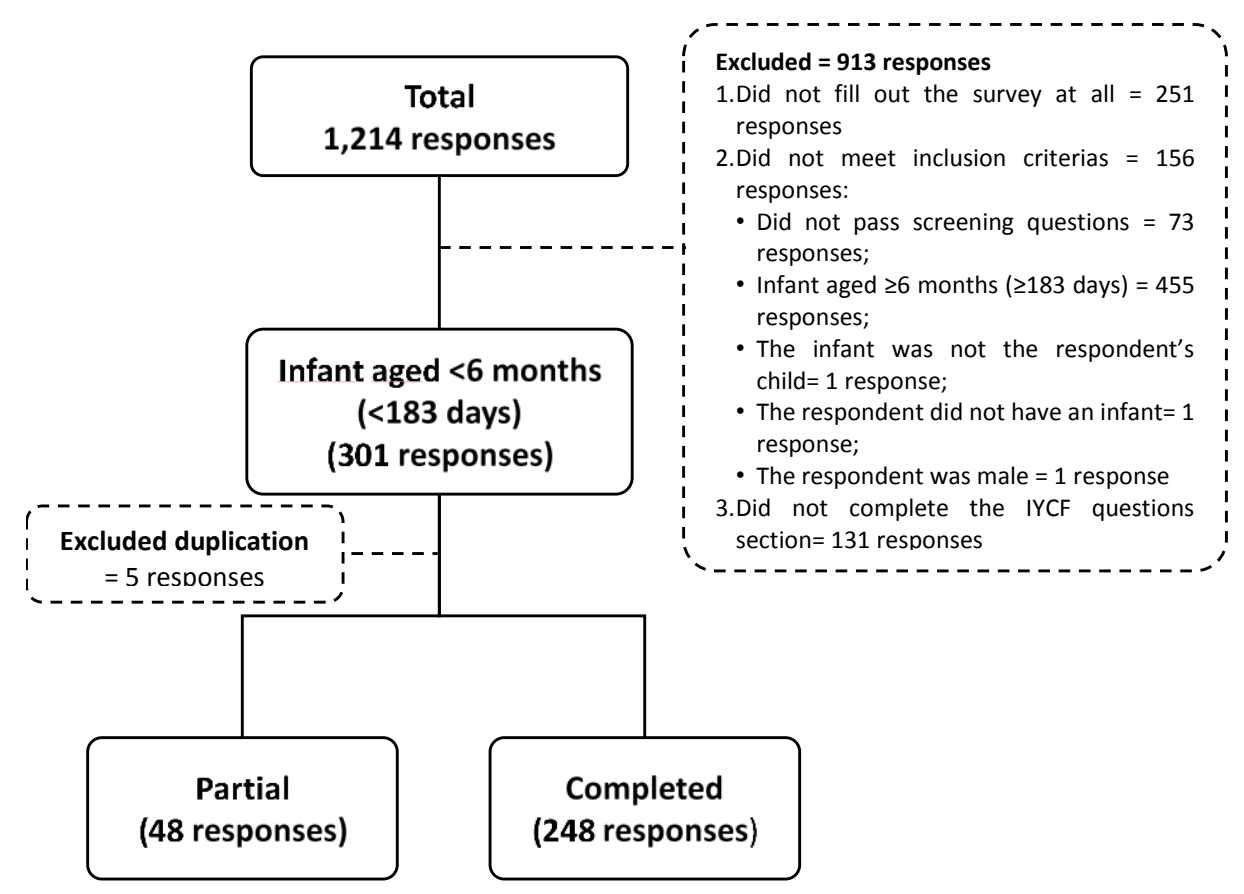

Figure 1. Diagram of subjects obtained in the study.

Mother's and infant's characteristics are presented in Table $\mathbf{1 .}$ Most of the subjects were aged between 18-34 years with a median of age of 29 years old, $86.7 \%$ had a diploma to master degree, $45.6 \%$ was housewife, and $39.2 \%$ had household income in the last 1-month range Rp.3,000,000 - Rp.7,199,999 (equal to USD $206.9-496.4$ ), and $83.1 \%$ was living in Java Island, with the West Java Province was the highest proportion among all provinces. Infant's characteristics included a median of age was 3 months, with $76.2 \%$ was aged $\leq 4$ months, $94.4 \%$ was normal birth weight/NBW (2,500 - 4,000 gram), and $96.0 \%$ was full-term (37-42 weeks).

Table 1. Distribution of mothers' and infants' characteristics ( $N=248)$

\begin{tabular}{ll}
\hline \multicolumn{1}{c}{ Characteristics } & \multicolumn{1}{c}{\begin{tabular}{c}
\multicolumn{1}{c}{ Proportion } \\
$\mathbf{n}(\boldsymbol{\%})$
\end{tabular}} \\
\hline Mothers & \multicolumn{1}{c}{$29(20-44)^{1}$} \\
Age & $225(90.7)$ \\
$18-34$ years old & $23(9.3)$ \\
$\geq 35$ years old & \\
Education level & $33(13.3)$ \\
$\quad$ Elementary to senior high school & $215(86.7)$ \\
$\quad$ Diploma to master degree & \\
Occupation & $34(13.7)$ \\
Civil servants/police/army & $54(21.8)$ \\
Private or state employee & $21(8.4)$ \\
Entrepreuner, freelancer, student & $113(45.6)$ \\
Housewife &
\end{tabular}




\begin{tabular}{|c|c|}
\hline Characteristics & $\begin{array}{l}\text { Proportion } \\
\text { n }(\%)\end{array}$ \\
\hline Others $^{2}$ & $26(10.5)$ \\
\hline \multicolumn{2}{|l|}{ Household income in the last 1 month } \\
\hline$\leq \mathrm{Rp} .2,999,999$ & $54(21.8)$ \\
\hline Rp.3,000,000 - Rp.7,199,999 & $97(39.2)$ \\
\hline$\geq$ Rp.7,200,000 & $97(39.1)$ \\
\hline \multicolumn{2}{|l|}{ Living location ${ }^{3}$} \\
\hline $\begin{array}{l}\text { Sumatera island (Aceh, North \& West Sumatera, Riau, Jambi, } \\
\text { Bengkulu, and Lampung Provinces) }\end{array}$ & $19(7.7)$ \\
\hline \multicolumn{2}{|l|}{ Java island } \\
\hline \multicolumn{2}{|l|}{ Jakarta Province } \\
\hline West Java Province & $49(19.8)$ \\
\hline Central Java Province & $70(28.2)$ \\
\hline Yogyakarta Province & $26(10.5)$ \\
\hline East Java Province & $18(7.3)$ \\
\hline Banten Province & $19(7.7)$ \\
\hline Bali \& Nusa Tenggara island (Bali, West \& East Nusa & $24(9.7)$ \\
\hline Tenggara Provinces) & $3(1.2)$ \\
\hline \multicolumn{2}{|l|}{ Kalimantan Island (West \& East Kalimantan Provinces) } \\
\hline \multirow{2}{*}{$\begin{array}{l}\text { Sulawesi island (North, South, Southeast, and West Sulawesi } \\
\text { Provinces) }\end{array}$} & $9(3.6)$ \\
\hline & $11(4.4)$ \\
\hline \multicolumn{2}{|l|}{ Infants } \\
\hline Age & $3(0-5)^{1}$ \\
\hline$\leq 4$ months & $189(76.2)$ \\
\hline$>4$ months & $59(23.8)$ \\
\hline \multicolumn{2}{|l|}{ Sex } \\
\hline Male & $127(51.2)$ \\
\hline Female & $121(48.8)$ \\
\hline Birthweight & $3,100(2,000-4,500)^{1}$ \\
\hline LBW $(<2,500$ gram $)$ & $6(2.4)$ \\
\hline NBW $(2,500-4,000$ gram $)$ & $234(94.4)$ \\
\hline $\mathrm{HBW}(>4,000$ gram $)$ & $8(3.2)$ \\
\hline Gestational age & $39(32-42)^{1}$ \\
\hline Pre-term (<37 weeks) & $10(4.0)$ \\
\hline Full-term ( $37-42$ weeks) & $238(96.0)$ \\
\hline $\begin{array}{l}{ }^{1} \text { Median (Min-Max) } \\
{ }^{2} \text { Other occupations included teachers, early childhood educator } \\
\text { government employee, doctor, contract or temporary employees } \\
\text { assistant, and researcher }\end{array}$ & $\begin{array}{l}\text { lecturer, non-civil servant } \\
\text { herapist, farmer, laboratory }\end{array}$ \\
\hline
\end{tabular}

Table 2 presents the current breastfeeding practices pattern of the subjects. It showed that of 248 subjects, $79.0 \%$ were exclusively breastfed. Other subjects were predominantly breastfeeding, practicing formula feeding, and combination feeding, respectively $10.5 \%, 2.4 \%$, and $8.1 \%$ of the total subjects. Among the subjects who gave mixed feeding, it was identified that the types of food items that had been given to their baby were quite diverse, ranging from commercial baby food, rice, and cereal groups, vegetables, and fruit, to animal protein sources. Sources of support for infant feeding that mother reported receiving during the COVID-19 pandemic is demonstrated in Table 3 . The most common sources of support for infant feeding were obtained from 
husbands $(91.1 \%)$ and health workers $(65.7 \%)$, followed by family $(62.9 \%)$. Other supports that reported were from friends (37.9\%), support groups (26.2\%), and online sources $(16.1 \%)$. Results of bivariate analysis (Table 4) revealed no significant associations between all of the sources of infant feeding support with exclusive breastfeeding. However, the proportion of exclusive breastfeeding practices among subjects who did not receive husband support $(68.2 \%)$ was lower than those who receive husband support

Table 2. Distribution of current breastfeeding practices pattern $(\mathrm{N}=\mathbf{2 4 8})$

\begin{tabular}{lc}
\hline \multicolumn{1}{c}{ Breastfeeding practice } & $\begin{array}{c}\text { Proportion } \\
\text { n (\%) }\end{array}$ \\
\hline Exclusive breastfeeding & $196(79.0)$ \\
Predominantly breastfeeding & $26(10.5)$ \\
Formula feeding & $6(2.4)$ \\
Combination feeding (breast milk/formula milk + semi-solid/solid food) & $20(8.1)$ \\
\hline
\end{tabular}

Table 3. Distribution of sources of infant feeding supports $(\mathrm{N}=\mathbf{2 4 8})$

\begin{tabular}{lc}
\hline \multicolumn{1}{c}{ Source of breastfeeding supports } & $\begin{array}{c}\text { Proportion } \\
\mathbf{n}(\mathbf{\%})\end{array}$ \\
\hline Husband & $226(91.1)$ \\
Family & $156(62.9)$ \\
Health professional & $163(65.7)$ \\
Friends & $94(37.9)$ \\
Social group ${ }^{1}$ & $65(26.2)$ \\
Online sources ${ }^{2}$ & $40(16.1)$ \\
\hline \multicolumn{2}{c}{${ }^{\text {II }}$ More than 20 social groups were identified including AIMI, Ayah ASI, Mommy Squad, } \\
Selasi (Yayasan Sentra Laktasi Indonesia), Pejuang ASI Indonesia, Birth Club Indonesia, \\
Exclusive Pumping Mama Indonesia (E-ping), Homemade Healthy Baby Food (HHBF), \\
Gema Indonesia Menyusui (GIM), Aku Cinta ASI Indonesia, Ambubaba birth club, \\
Komunitas MPASI Homemade (KMHM), Sentra Laktasi Muslimah/Salma, NGASIyuk, \\
etc. \\
2 Online sources which were web-based, mobile apps-based, forum discussion or more \\
were identified, including Orami parenting, The Asian Parents, Kursusku.id, Healthcare \\
Pedia Indonesia (Support Group HaPpy), gaiaparenting.com, Kelas Menyusui Online \\
(KMO), Ibupedia.com, femaledaily.com/mommiesdaily.com, etc.
\end{tabular}

Table 4. Association between Sources of Breastfeeding Supports and Exclusive Breastfeeding Practices $(\mathrm{N}=\mathbf{2 4 8})$

\begin{tabular}{lccccc}
\hline \multicolumn{1}{c}{ Variables } & \multicolumn{2}{c}{$\begin{array}{c}\text { Exclusive Breastfeeding } \\
\text { Practices }\end{array}$} & Total & $\begin{array}{c}\boldsymbol{p} \text { - } \\
\text { value }\end{array}$ & $\begin{array}{c}\text { Crude OR } \\
\text { (95\% CI) }\end{array}$ \\
\cline { 2 - 3 } & $\begin{array}{c}\text { Non-EBF } \\
\mathbf{n}(\%)\end{array}$ & $\begin{array}{c}\mathbf{E B F} \\
\mathbf{n}(\%)\end{array}$ & & & \\
\hline Husband support & $7(31.8)$ & $15(68.2)$ & 22 & $0.269^{\mathrm{b}}$ & $1.8(0.723-4.876)$ \\
$\quad$ No & $45(19.9)$ & $181(80.1)$ & 226 & & 1 \\
$\quad$ Yes & & & & & $1.7(0.892-3.340)$ \\
Family \& Friends support & $18(28.1)$ & $46(71.9)$ & 64 & 0.102 & 1 \\
$\quad$ No & $34(18.5)$ & $150(81.5)$ & 184 & & \\
$\quad$ Yes & & & &
\end{tabular}




\begin{tabular}{|c|c|c|c|c|c|}
\hline \multirow{2}{*}{ Variables } & \multicolumn{2}{|c|}{$\begin{array}{c}\text { Exclusive Breastfeeding } \\
\text { Practices }\end{array}$} & \multirow{2}{*}{ Total } & \multirow{2}{*}{$\begin{array}{c}p- \\
\text { value }^{\mathrm{a}}\end{array}$} & \multirow{2}{*}{$\begin{array}{c}\text { Crude OR } \\
(95 \% \mathrm{CI})\end{array}$} \\
\hline & $\begin{array}{c}\text { Non-EBF } \\
\text { n }(\%)\end{array}$ & $\begin{array}{c}\text { EBF } \\
\mathbf{n}(\%)\end{array}$ & & & \\
\hline No & $21(24.7)$ & $64(75.3)$ & 85 & 0.296 & $1.3(0.745-2.621)$ \\
\hline Yes & $31(19.0)$ & $132(81.0)$ & 163 & & 1 \\
\hline \multicolumn{6}{|c|}{ Social group \& online supports } \\
\hline No & 35 (21.9) & $125(78.1)$ & 160 & 0.636 & $1.2(0.611-2.237)$ \\
\hline Yes & $17(19.3)$ & $71(80.7)$ & 88 & & 1 \\
\hline Total & $52(21.0)$ & $196(79.0)$ & 248 & & \\
\hline
\end{tabular}

\section{DISCUSSION}

The result of this study showed that the proportion of exclusive breastfeeding practice among subjects was high (79.0\%). The proportion was higher than the national exclusive breastfeeding rate in $2019(67.74 \%)$ [24]. In line with this, the results from a similar study during the early COVID-19 pandemic period in 6 provinces in Indonesia through rapid survey showed that infants aged under 6 months that only fed breast milk on the previous day was $87.8 \%$ [25]. The positive impact of the COVID-19 pandemic that might improve exclusive breastfeeding practices is mothers had much time to focus on feeding their baby, so did partner to support mothers during work from home [26]. In addition, it might be due to most of mothers who already breastfeeding did not have a plan or consideration to stop breastfeeding during the COVID-19 pandemic [27].

In this study, the most source of support that subjects received was from their husband/partner. Similar findings were also found from a study on the experience and infant feeding practice of new mothers during the COVID-19 pandemic in England which showed that the most source of support that mother received and the most influential support that mother perceived were husband/partner [28]. This can be explained that the available time of husband/partner to support mother was increased when working from home [26]. Husband/partner becomes a valuable source of support for mother through his active participation in childcare, especially when mother experienced limited access to family members or friends who may provide this support before pandemic [28]. Ogbo et al found different types of supportive parental behavior, which are support in the form of verbal encouragement and support in the form of actions [29]. While, Davidson and Ollerton categorized parental supportive behaviors as knowledge, help, encouragement, and responsiveness [30]. Health professional support, as well as family and friend support, also became the most breastfeeding supports that mothers received during the pandemic. As the family is the closest environment for mother and infant, the family becomes the first setting for the motherinfant dyad in infant feeding practices, specifically breastfeeding after discharge from the health care facility [31,32]. The roles of family in providing the values and beliefs in breastfeeding practices [33]. Health professionals or health workers are more skilled and experienced, so they can help mothers with health risked circumstances that can result in delayed breastfeeding, for example, high-risk pregnancy, assisted 
delivery and long hospital stays, maternal illness, low-birthweight newborn babies, and preterm, ill [6]. Breastfeeding support and service from health care facilities were received during antenatal care (ANC), delivery, and postnatal care (PNC).

The bivariate analyses show that the husband's support was not significantly associated with exclusive breastfeeding, which is consistent with a previous study in Indonesia [34]. Decision-making in exclusive breastfeeding by mothers might explain why some mothers who received husband's support still did not practice exclusive breastfeeding. Several factors might influence a mother's decision in breastfeeding, including sociodemographic characteristics, personal experiences, social and professional support, changes to the family dynamic, etc $[35,36]$. The involvement of the husband in the mother's decision-making process of breastfeeding is determined by the mother's perception, which commonly mothers perceive that husband is not part of breastfeeding decision and most of the time husband felt left out [37]. However, the proportion of exclusive breastfeeding among mothers who received husband support was higher than those who did not receive husband support. This might be caused by the positive impact of the COVID-19 pandemic that mother's perceived, such as fewer visitors that give mothers more time to focus and relax on feeding their baby, can increase confidence in breastfeeding due to enhanced mother's privacy, increased responsive feeding due to less of household routine, and had much husband support when working from home [26].

Family and friend supports was not significantly associated with exclusive breastfeeding. It is inconsistent with previous studies in Indonesia that showed family supports was positively associated with exclusive breastfeeding $[33,38]$. Family provides mothers the values and beliefs in breastfeeding practices [33]. This different finding might happen because mothers are able to decide which family supports they should accept or reject, especially for the supports that mothers considered harmful to the breastfeeding practices and maintaining exclusive breastfeeding [39].

Health professional support also was not associated with exclusive breastfeeding, which previous studies had similar results [40,41]. In contrast, other several previous studies in Indonesia showed a significant association between health worker/health care facilities support with exclusive breastfeeding practices [32]'[42]. Different findings might be because of an unspecific period of health professional support that mothers received in this study. Health workers' or health professionals' supports for mothers is important in a critical period of the newborn during the hospital stay and after discharge from hospital for stabling lactation and lowering the risk of exclusive breastfeeding termination [6]'[43]'[44].

No association between social groups \& online supports with exclusive breastfeeding practice was also found in this study. A systematic review and metaanalysis study found that no difference in the proportion of exclusive breastfeeding until 6 months between mothers who received peer support and those who did not in high-income countries [45]. This might be due to a preference to get advice and support on breastfeeding from professional health workers among mothers in high-income countries [45]. Similarly, the previous study in the UK among infants born during lockdown vs before lockdown in the COVID-19 pandemic showed that only fewer among infants born during lockdown group perceived online support as the main influence on infant feeding compared to 
infants born before lockdown group [46]. Mothers with younger infants needed more practical support for the establishment of breastfeeding [46]. While online support commonly is used by mothers for seeking informational support [47]. However, this kind of support has the potential to be utilized more in the effort to improve breastfeeding practices as the development of maternal and child health support groups and the increasing use of digital technology in disseminating health information even before the pandemic. As the univariate results, more than 20 support groups and online supports were identified. The types of online supports that mothers used/received were commonly application-based, web-based, or social media-based online supports. While for the social group support, it was also mostly obtained in an online manner (e.g. social media, webinar, online course, etc.) due to the movement control order during pandemic circumstances. Similarly, Brown and Shenker reported from a study in the UK that mothers hardly access face-to-face support from social group support [26]. The characteristic of online based-social support was a virtual community that has many members from experienced mothers, easy to access, also some of them available in different regions [48]. Furthermore, online groups can effectively help mother with anxiety problem that avoids attending face-toface groups and provide time flexibility to be accessed [49]. Thus, this kind of support is still relevant for mothers in pandemic circumstances. However, several considerations for the utilization of online support were the misinformation or invalid information that was sometimes posted, lack of regulation, polarized debate or judgment for using not breastfeed or using infant formula, etc [49]. Therefore, it is suggested to have a high literacy on digital information or the internet and still need to be accompanied by health professionals to obtain valid information.

The current study was the large survey observing the source of infant feeding supports and exclusive breastfeeding practice among mothers during the COVID-19 pandemic, which is still limited to being discussed in previous studies, especially in Indonesia. This study has the limitation that the overall prevalence of exclusive breastfeeding was based on the mother's self-reported infant feeding information at the previous 24 hours, which might lead to recall bias. However, the exclusive breastfeeding practice in this study was assessed based on a standard and valid questionnaire that was also used widely on a national survey. In addition, this study only observed current exclusive breastfeeding practices that might not be interpreted as 6 monthexclusive breastfeeding practices as WHO recommendation. Another concern is the socio-demographic characteristic of the subjects that mostly were 18-34 years old, had high education and income level, and lived in Java Island that might be due to the accessibility of the internet or literacy of information and technology. Therefore, the findings in this study cannot be directly generalized to Indonesian population.

\section{CONCLUSIONS}

The findings of this study show that various sources of supports on breastfeeding for mothers are still relevant and needed to ensure exclusive breastfeeding practices during pandemic circumstances. The most sources of supports that mothers obtained were from the home environment (husband and family or significant others), as well as health professionals. Government should target mothers and their husband or family as a priority target for health 
professionals to provide preventive and promotive breastfeeding intervention because the most sources of support in infant feeding that mothers perceived were husband, health professional, and family. In pandemic circumstances, the modification and innovation of ANC visits or any other mother and children health services are needed. Mothers can use online counseling or home visitation to access ANC services or any other source of supports on breastfeeding. Future analyses of the survey data are needed to explore more about mother's experiences change, such as everyday lifestyle, finances, access, and utilization in healthcare services to get the whole picture of the effects of the COVID-19 pandemic on exclusive breastfeeding practices. Furthermore, the survey should cover all Indonesia regions with more diverse samples.

\section{ACKNOWLEDGEMENT}

This study was supported by the Southeast Asian Ministers of Education Organization - Regional Centre for Food and Nutrition (SEAMEO RECFON).

\section{REFERENCES}

1. Kementerian Kesehatan RI. Laporan Nasional Riskesdas 2018. Jakarta; 2018.

2. Arif S, Isdijoso W, Fatah AR, Tamyis AR. Strategic Review of Food Security and Nutrition in Indonesia: 2019-2020 Update. Jakarta; 2020.

3. Kementerian Kesehatan RI. Riset Kesehatan Dasar (RISKESDAS) Tahun 2013. Jakarta; 2013.

4. Headey D, Heidkamp R, Osendarp S, Ruel M, Scott N, Black R, et al. Impacts of COVID-19 on childhood malnutrition and nutrition-related mortality. Lancet. 2020;6736(20):12.

5. United Nation Children's Fund. COVID-19 dan Anak-Anak di
Indonesia: Agenda Tindakan untuk Mengatasi Tantangan Sosial Ekonomi [Internet]. United Nation Children's Fund (UNICEF). 2020 [cited 2020 Aug 5]. p. 5. Available from:

https://www.unicef.org/indonesia/rep orts/covid-19-and-children-inindonesia

6. Rollins NC, Bhandari N, Hajeebhoy $\mathrm{N}$, Horton S, Lutter CK, Martines $\mathrm{JC}$, et al. Why invest, and what it will take to improve breastfeeding practices? Lancet. 2016;387(10017):491-504.

7. United Nations Children's Fund. Programming Guide: Infant and Young Child Feeding [Internet]. United Nation Children's Fund (UNICEF). 2011 [cited 2020 Aug 5]. p. 3. Available from: http://www.unicef.org/nutrition/files/ Final_IYCF_programming_guide_20 11.pdf

8. Sachdeva RC, Jain S, Mukherjee S, Singh J. Ensuring Exclusive Human Milk Diet for All Babies in COVID19 Times. Indian Pediatr. 2020;09:18.

9. United Nations Children's Fund. The State of Children in Indonesia Trend, Opportunities and Challenges for Realizing Children's Rights [Internet]. United Nation Children's Fund. Jakarta; 2020. Available from: http://reliefweb.int/sites/reliefweb.int /files/resources/141 Snet The State of Children in Asian Cities.pdf

10. WHO, UNICEF. Global Nutrition Target 2025: Breastfeeding Policy Brief (WHO/MNH/NHD/14.7). Geneva; 2014.

11. Hector D, King L, Webb K, Heywood P. Factors affecting breastfeeding practices: applying a conceptual framework. N S W Public Health Bull. 2005;16(3-4):52-5.

12. Busch-Hallen J, Walters D, Rowe S, Chowdhury A, Arabi M. Impact of 
COVID-19 on maternal and child health. Lancet Glob Heal [Internet]. 2020;8(10):e1257. Available from: http://dx.doi.org/10.1016/S2214109X(20)30327-2

13. Varghese A, Agarwal M. Safeguarding nutritional opportunities of first 1000 days of life during a pandemic: infant and young children feeding practices in the context of COVID-19 in India. Int J Community Med Public Heal. 2020;7(7):2836-40.

14. Brooks SK, Webster RK, Smith LE, Woodland L, Wessely S, Greenberg $\mathrm{N}$, et al. The psychological impact of quarantine and how to reduce it: a rapid review of the evidence. Lancet. 2020;395(10227):912-20.

15. Thapa SB, Mainali A, Schwank SE, Acharya G. Maternal mental health in the time of the COVID-19 pandemic. Acta Obstet Gynecol Scand. 2020;99(7):817-8.

16. Peduzzi P, Concato J, Kemper E, Holford TR, Feinstein AR. A Simulation Study of the Number of Events per Variable in Logistic Regression Analysis. J Clin ep. 1996;49(12):1373-9.

17. Badan Penelitian dan Pengembangan Kesehatan. Riset Kesehatan Dasar 2018 (Kuesioner Individu) [Internet]. Jakarta: Kementerian Kesehatan RI; 2018. Available from: https://labmandat.litbang.kemkes.go. id/images/download/kuesioner/RKD/ 2018/236-kues_ind_rkd18.pdf

18. Badan Kependudukan dan Keluarga Berencana Nasional, Badan Pusat Statistik, Kementerian Kesehatan, USAID. Survey Demografi dan Kesehatan Indonesia 2017. Jakarta; 2018.

19. WHO. Indicators for assessing infant and young child feeding practices: Part 1 Definitions. World Health Organization. Geneva: World Health Organization; 2007. 1-19 p.
20. Dewitt J, Capistrant B, Kohli N, Simon Rosser BR, Mitteldorf D, Merengwa E, et al. Addressing participant validity in a small internet health survey (the restored study): Protocol and recommendations for survey response validation. J Med Internet Res. 2018;20(4).

21. Pozzar R, Hammer MJ, UnderhillBlazey M, Wright AA, Tulsky JA, Hong F, et al. Threats of bots and other bad actors to data quality following research participant recruitment through social media: Cross-sectional questionnaire. J Med Internet Res. 2020;22(10).

22. Teitcher JEF, Bockting WO, Bauermeister JA, Hoefer CJ, Miner MH, Klitzman RL. Detecting, Preventing and Responding to "Fraudsters" in Internet Research: Ethics and Tradeoffs. J Law Med Ethics. 2015;43(1):116-33.

23. Leiner DJ. Too fast, too straight, too weird: Non-reactive indicators for meaningless data in internet surveys. Surv Res Methods. 2019;13(3):229_ 48.

24. Kementerian Kesehatan RI. Profil Kesehatan Indonesia Tahun 2019. Vol. 53. Jakarta: Kementerian Kesehatan RI; 2020. 145 p.

25. Muslimatun S. Pemberian Makan Bayi dan Anak (PMBA) Selama Masa Pandemi: Survey Cepat di 6 Provinsi di Pulau Jawa. Jakarta: Direktorat Gizi dan Masyarakat Kemenkes RI; 2021.

26. Brown A, Shenker N. Experiences of breastfeeding during COVID-19: Lessons for future practical and emotional support. Matern Child Nutr. 2020;(June):e13088.

27. Burgess A, Breman RB, Bradley D, Dada S, Burcher P. Pregnant Women's Reports of the Impact of COVID-19 on Pregnancy, Prenatal Care, and Infant Feeding Plans. MCN Am J Matern Child Nurs. 
2021;46(1):21-29.

28. Vazquez-Vazquez A, Dib S, Rougeaux E, Wells JC, Fewtrell MS. The impact of the Covid-19 lockdown on the experiences and feeding practices of new mothers in the UK: Preliminary data from the COVID-19 New Mum Study. Appetite. 2021;156(September 2020):104985.

29. Agho KE, Ezeh OK, Ghimire PR, Uchechukwu OL, Stevens GJ, Tannous WK, et al. Exclusive breastfeeding rates and associated factors in 13 "economic community of West African states" (ECOWAS) countries. Nutrients. 2019;11(12).

30. Davidson EL, Ollerton RL. Partner behaviors improving breastfeeding outcomes: An integrative review. Women and Birth. 2020;33(1):e1523.

31. Arifah I, Rahayuning $P$ D, Rahfiludin MZ. Father'S Roles on the Exclusive Breastfeeding Practice. J Kesehat Masy (Journal Public Heal. 2014;8(2):83-92.

32. Februhartanty J, Muslimatun S, Shankar AH, Djakababa N, Suradi R. Paternal Roles in Breastfeeding in Jakarta, Indonesia: A Mixed-method Approach. Indones J Hum Nutr. 2018;7(1):31-43.

33. Atika Z, Salimo H, Dewi YLR. Multilevel Analysis on the Determinants of Exclusive Breastfeeding at Gunung Anyar Community Health Center, Surabaya, Indonesia. J Matern Child Heal. 2018;03(03):76-183.

34. Suryani D, Simbolon D, Elly N, Pratiwi BA, Yandrizal. Determinants failures of Exclusive Breastfeeding on Health Workers in Bengkulu. J Kesehat Masy [Internet]. 2017;12(2). Available from: http://journal.unnes.ac.id/nju/index.p hp/kemas\%0AFAKTOR

35. Primo CC, De Oliveira Nunes B, De
Fátima Almeida Lima E, Leite FMC, De Pontes MB, Brandão MAG. Which factors influence women in the decision to breastfeed? Investig y Educ en Enferm. 2016;34(1):198210.

36. Asiodu I V., Waters CM, Dalley DE, Lyndon A. Infant Feeding DecisionMaking and The Influences of Social Support Persons among First-Time African American Mothers. Matern Child Health J. 2017;21(4):863-72.

37. Gebremariam KT, Zelenko O, Mulugeta A, Gallegos D. A crosssectional comparison of breastfeeding knowledge, attitudes, and perceived partners' support among expectant couples in Mekelle, Ethiopia. Int Breastfeed J. 2021;16(1):1-8.

38. Rapingah S, Muhani N, Besral, Yuniar P. Determinants of exclusive breastfeeding practices of female healthcare workers in Jakarta, Indonesia. Kesmas Natl Public Heal J. 2021;16(1):59-65.

39. Theodorah DZ, Mc'Deline RN. "The kind of support that matters to exclusive breastfeeding": a qualitative study. BMC Pregnancy Childbirth. 2021;21(119):1-8.

40. Latorre G, Martinelli D, Guida P, Masi E, Benedictis R De, Maggio L. Impact of COVID-19 pandemic lockdown on exclusive breastfeeding in non-infected mothers. Int Breastfeed J. 2021;16(36):1-7.

41. Yuniarini WR, Herini ES, Wahab A. Postpartum lactation counseling and exclusive breastfeeding: Analysis of the 2017 Indonesian demographic and health survey. Paediatr Indones Indones. 2021;61(1):25-33.

42. Sinta P, Salimo H, Pamungkasari EP. Multilevel Analysis on the Biosocial and Economic Determinants of Exclusive Breastfeeding. J Matern Child Heal. 2017;02(04):356-70.

43. WHO, UNICEF. Protecting, 
promoting and supporting breastfeeding: the baby-friendly hospital initiative for small, sick and preterm newborns [Internet]. Geneva: World Health Organization and the United Nations Children's Fund (UNICEF); 2020. 1-56 p. Available from: https://www.who.int/publications/i/it em/9789240005648

44. Gianni ML, Bettinelli ME, Manfra P, Sorrentino G, Bezze E, Plevani L, et al. Breastfeeding difficulties and risk for early breastfeeding cessation. Nutrients. 2019;11(10):1-10.

45. Shakya P, Kunieda MK, Koyama M, Rai SS, Miyaguchi M, Dhakal S, et al. Effectiveness of communitybased peer support for mothers to improve their breastfeeding practices: A systematic review and meta-analysis. PLoS One. 2017;12(5).

46. Vazquez-Vazquez A, Dib S, Rougeaux E, Wells JC, Fewtrell M.
The impact of the Covid-19 lockdown on the experiences and feeding practices of new mothers in the UK: Preliminary data from the COVID-19 New Mum Study. medRxiv [Internet]. 2020;2020.06.17.20133868.

Available from: https://www.medrxiv.org/content/10. 1101/2020.06.17.20133868v1

47. Wagg AJ, Callanan MM, Hassett A. Online social support group use by breastfeeding mothers: A content analysis. Heliyon. 2019;5:e01245.

48. Moon H, Woo K. An integrative review on mothers' experiences of online breastfeeding peer support: Motivations, attributes and effects. Maternal and Child Nutrition. Blackwell Publishing Ltd; 2021.

49. Regan S, Brown A. Experiences of online breastfeeding support: Support and reassurance versus judgment and misinformation. Matern Child Nutr. 2019;15(4). 